\title{
Path Analysis: The Effect of Biopsychosocial and Environmental Exposure on Child Asthma in Surakarta
}

\author{
Ayunita Dwi Hadianti'), Uki Retno Budihastuti²), Yulia Lanti Retno Dewi3) \\ 1)Masters Program in Public Health, Universitas Sebelas Maret \\ 2)Department of Obstetrics and Gynecology, Dr. Moewardi Hospital, Surakarta \\ 3)Department of Nutrition, Faculty of Medicine, Universitas Sebelas Maret
}

\begin{abstract}
Background: Asthma is a non-communicable disease with high morbidity in Indonesia. According to David Barker's fetal origin hypothesis, biopsychosocial as well as environmental exposure during gestational period affect health outcome in later life. This study aimed to determine the effect of bio-psychosocial and environmental exposure factor on the risk of child asthma in Surakarta.

Subjects and Method: This was an analytical observational study with case control design. This study was conducted at the Center for Community Pulmonary Health (BBKPM), Surakarta. A total of 105 study subjects were selected by fixed disease sampling, consisting of 35 asthmatic patients and 70 healthy children aged 6-15 year old. The exogenous variables were maternal education, current child stress, indoor cigarette smoke exposure and maternal stress during gestational period, current family income, and current indoor cigarette smoke exposure. The endogenous variables were birth weight and child asthma. The data were collected by a set of questionnaire and analyzed using path analysis model.

Results: Current child stress $(b=3.49 ; 95 \% \mathrm{CI}=1.18$ to $5.81 ; \mathrm{p}=0.003)$, exposure to indoor cigarette smoke $(b=3.44 ; 95 \% \mathrm{CI}=1.07$ to $5.80 ; \mathrm{p}=0.004)$, indoor air polution $(\mathrm{b}=2.43 ; 95 \% \mathrm{CI}=$ 0.60 to 4.27; $\mathrm{p}=0.009$ ), had positive, direct, and statistically significant effects on the risk of child asthma. Birth weight $\geq 2,500 \mathrm{~g}(\mathrm{~b}=-2.01 ; 95 \% \mathrm{CI}=-3.95$ to $-0.07 ; \mathrm{p}=0.041)$ had negative, direct, and statistically significant effect on the risk of child asthma. Maternal education had positive and statistically significant effect on family income $(b=1.57 ; 95 \% \mathrm{CI}=0.62$ to $2.52 ; \mathrm{p}=0.001)$. Family income had negative and statistically significant effect on indoor air pollution $(b=-2.48 ; 95 \% \mathrm{CI}=-$ 3.52 to $-1.44 ; \mathrm{p}=0.001)$. Maternal stress at gestational period had negative and statistically significant effect on birth weight $(b=-1.13 ; 95 \% \mathrm{CI}=-2.18$ to $-0.08 ; \mathrm{p}=0.035)$.

Conclusion: In line with David Barker's fetal origin hypothesis, this study supports that biopsychosocial as well as environmental factors have significant effects on child asthma.
\end{abstract}

Keywords: bio-psychosocial, environmental exposure, asthma, children.

\section{Correspondence:}

Ayunita Dwi Hadianti. Masters Program in Public Health, Universitas Sebelas Maret, Jl. Ir. Sutami 36 A, Surakarta 57126, Central Java. Email: ayunitadwihadianti@gmail.com.

Mobile: +6282314064445 .

\section{BACKGROUND}

Asthma is a non-communicable disease that causes morbidity and mortality because of uncontrolled asthma attack. Based on Global Burden of Disease Study, more than 345,000 people globally died for asthma (Lozano et al., 2012). In Indonesia, asthma is rarely reported yet it can cause sudden death, it is illustrated from the study data of Survei Kesehatan Rumah Tangga (SKRT) or Household Health Survey of Health Department of the Republic of Indonesia in 2004 that in various provinces in Indonesia asthma ranked 3 out of 10 as the leading causes of death in Indonesia (Sihombing et al., 2010). Based 
on the latest data from Sistem Informasi Rumah Sakit (SIRS) or Hospital Information System, mortality rate for asthma in Indonesia is 63,584 people (Depkes, 2014).

Asthma prevalence is increasing in the last two and a half century (Ferreira et al., 2010). The increase that occurs among children and infants is approximately $10 \%$ $85 \%$, it is higher than that of adults which is 5.4\% (Oemiati et al., 2010). Relatively big asthma prevalence also occurs in low economy level society. Various studies prove that social-economy factors such as income greatly contribute in the incidences of respiratory diseases (Machmud, 2009).

The cases of asthma in Surakarta in 2014 were included as the top three of the leading non-communicable diseases after hypertension and diabetes (Dinas Kesehatan Kota Surakarta, 2014). Based on preliminary study in Center for Community Pulmonary Health of Surakarta, the number of visits of asthma patients in the last three years was fluctuating. In 2013 there were 882 patients, 461 patients in 2014, in 2015 it decreased into 264 patients and it was estimated to be increasing in 2016 since there were 379 patients up to the month of July.

The risk of asthma development is an interaction between host factor and environmental factor. The host factor here includes genetic predisposition that influences the development of asthma, namely genetic, allergy (atopy), brochus hyper activity, sex category, and race. Environmental factor includes allergen, cigarette smoke, air pollution, diet, social economy status and the size of family (Perhimpunan Dokter Paru Indonesia, 2010).

Recent finding revealed that the risk of asthma is not merely caused by genetic and environmental factor, however it is also influenced by intrauterine environment since the gestational period (Wright, 2010).
Meta analysis study conducted by Guxens et al., (2014) revealed substantial evidence that psychological factor such as stress exposure during prenatal period as critical toxic exposure started from gestational period and permanently may change the system (of body immune, autonomic (nervous) system, neuro-endocrine and oxidetion system) that influence the development of lungs and respiratory disorder.

Stress exposure during gestational period generates performing unhealthy behavior such as smoking during prenatal and it leads to bigger risk for premature birth and low birth weight. Children who were born with low birth weight are susceptible to suffer undergo deterioration of respiratory function and have increased risk of chronic respiratory symptoms in their first seven years of life (Raheleh et al., 2016).

Meta-analysis study by $\mathrm{Xu}$ et al., (2014) stated that children who were born with low birth weight have $16 \%$ higher risk to suffer from asthma, the association is not in accordance with the facts, since low birth weight is not the only factor that contributes to the development of asthma. The influence of low birth weight toward asthma is as significant as other risk factors, such as family history of asthma and air pollution (Vernon et al., 2012).

Intervention in a form of primary prevention is greatly needed to reduce the risk of asthma as well as to increase individual and population health status by changing the wrong course of a lifetime journey (Murti, 2016). Based on the issue, researchers were interested to dig out deeper the causal factors of asthma both directly and indirectly among biological, psychological, social and environmental factor. Even though the effects between biopsychosocial factors with asthma incidence have been studied recently, however in Indonesia they are only few and there is still controversy 
on biopsychological factors toward mechanism of asthma occurrence

This study aimed to analyze the effects of biopsychosocial and environmental exposure toward asthma incidence on children.

\section{SUBJECTS AND METHOD \\ 1. Study Design \\ This was a case control study conducted in Jebres, Laweyan, Banjarsari, and Serengan Sub-Districts, Surakarta, Central Java, from November 1 to November 26, 2016.}

\section{Population and Sample}

The targeted population was children who live in Surakarta. The source population (accessible population) was children who lived in Jebres, Laweyan, Banjarsari, and Serengan Sub-Districts. A sample of 105 children aged 6-15 years was selected by using fixed disease sampling comprising 35 children with asthma and 70 children without asthma.

\section{Study Variables}

Table 1. Characteristics of Study Subjects

\begin{tabular}{llcc}
\hline \multicolumn{1}{c}{ Characteristics } & \multicolumn{1}{c}{ Criteria } & n & \% \\
\hline Child Age & Early Stage (6-7 years) & 52 & $49.5 \%$ \\
& Intermediate stage (8-9 years) & 21 & $20.0 \%$ \\
Sex Categories & Pre adolescence (10-15 years) & 32 & $30.4 \%$ \\
Maternal Occupation & Male & 56 & $53.3 \%$ \\
& Female & 49 & $46.6 \%$ \\
& Housewive (Unemployed) & 33 & $31.4 \%$ \\
& Laborer & 19 & $18.1 \%$ \\
& Private employee & 12 & $11.4 \%$ \\
Parental history of atopy & Self-employed & 28 & $26.6 \%$ \\
& Civil Servant & 13 & $12.3 \%$ \\
& Mother & 13 & $12.4 \%$ \\
& Father & 6 & $5.7 \%$ \\
& Aunt/ Uncle & 2 & $2.0 \%$ \\
& Grandmother/ Grandfather & 8 & $7.6 \%$ \\
& None & 5 & $4.8 \%$ \\
\hline
\end{tabular}

\section{Bivariate analysis}

Variables in bivariate analysis in Table 2 were children asthma status, cigarette smoke exposure, indoor air pollution, children psychology, maternal psychology
The dependent variable was asthma. The independent variables were maternal education, child psychology, smoke exposure, maternal stress during pregnancy, family income, indoor air pollution, and birth weight.

\section{Data collection}

Data on child asthma were obtained from Center for Community Pulmonary Health (BBKPM) Surakarta. The other variables were collected by questionnaire and record. The data were analyzed by path analysis run on Stata 13 program.

\section{RESULTS}

\section{Study Subjects Characteristics}

The result of study subject characteristics in Table 1 showed that as many as 52 children (49.5\%) were at early stage of age (6-7 years old). The number of male and female subjects were almost equal with 56 male (53.3\%) and 49 female (46.6\%). As many as 33 mothers $(31.4 \%)$ were working at home. 
$\mathrm{p}<0.001)$ and indoor air pollution $(\mathrm{OR}=$ increased the risk of asthma in children. $41.25 ; 95 \% \mathrm{CI}=11.84$ to $143.62 ; \mathrm{p}<0.001)$

\section{Table 2. Result of Bivariate Analysis}

\begin{tabular}{lcccc}
\hline \multicolumn{1}{c}{ Independent Variables } & \multirow{2}{*}{ OR } & \multicolumn{2}{c}{ 95\% CI } & p \\
\cline { 3 - 4 } & & Upper Limit & Lower Limit & \\
\hline Birth weight & 0.07 & 0.02 & 0.24 & $<0.001$ \\
Cigarette smoke exposure & 47.66 & 0.41 & 2.40 & $<0.001$ \\
Indoor air pollution & 41.25 & 11.84 & 143.62 & $<0.001$ \\
Child psychology & 48.72 & 12.51 & 189.67 & $<0.001$ \\
Maternal psychology during gestation & 2.21 & 0.86 & 5.70 & 0.095 \\
Family income & 0.01 & 0.01 & 0.07 & $<0.001$ \\
Maternal education & 0.18 & 0.07 & 0.45 & $<0.001$ \\
\hline
\end{tabular}

\section{Path analysis}

Multivariate analysis was conducted by using STATA 13 application with SEM (Structural Equation Modeling) program. Path analysis elaborated the factors that directly and indirectly affected the causes of asthma occurrence on children. Path analysis model was depicted in Figure 1. With the value of degree of freedom $(\mathrm{df})=21$ which meant over-identified therefore path analysis was possible to be conducted.

Table 3 showed the results of path analysis model. High indoor air pollution $(b=2.43 ; 95 \% \mathrm{CI}=0.60$ to $4.27 ; \mathrm{p}=0.009)$, high child stress $(b=3.49 ; 95 \% \mathrm{CI}=1.18$ to $5.81 ; \mathrm{p}=0.003$ ), and high exposure of cigarette smoke $(b=3.44 ; 95 \% \mathrm{CI}=1.07$ to $5.80 ; \mathrm{p}=0.004$ ) was directly increased the risk of child asthma. Birth weight $\geq 2,500 \mathrm{~g}$ reduced the risk of asthma in children.

Maternal education, family income, and maternal stress during pregnancy were indirectly associated with the risk of asthma in children.

Maternal education $\geq$ Senior high school $(b=1.57 ; 95 \% \mathrm{CI}=0.62$ to 2.52 ; $\mathrm{p}<0.001)$ increased the likelihood of high family income.

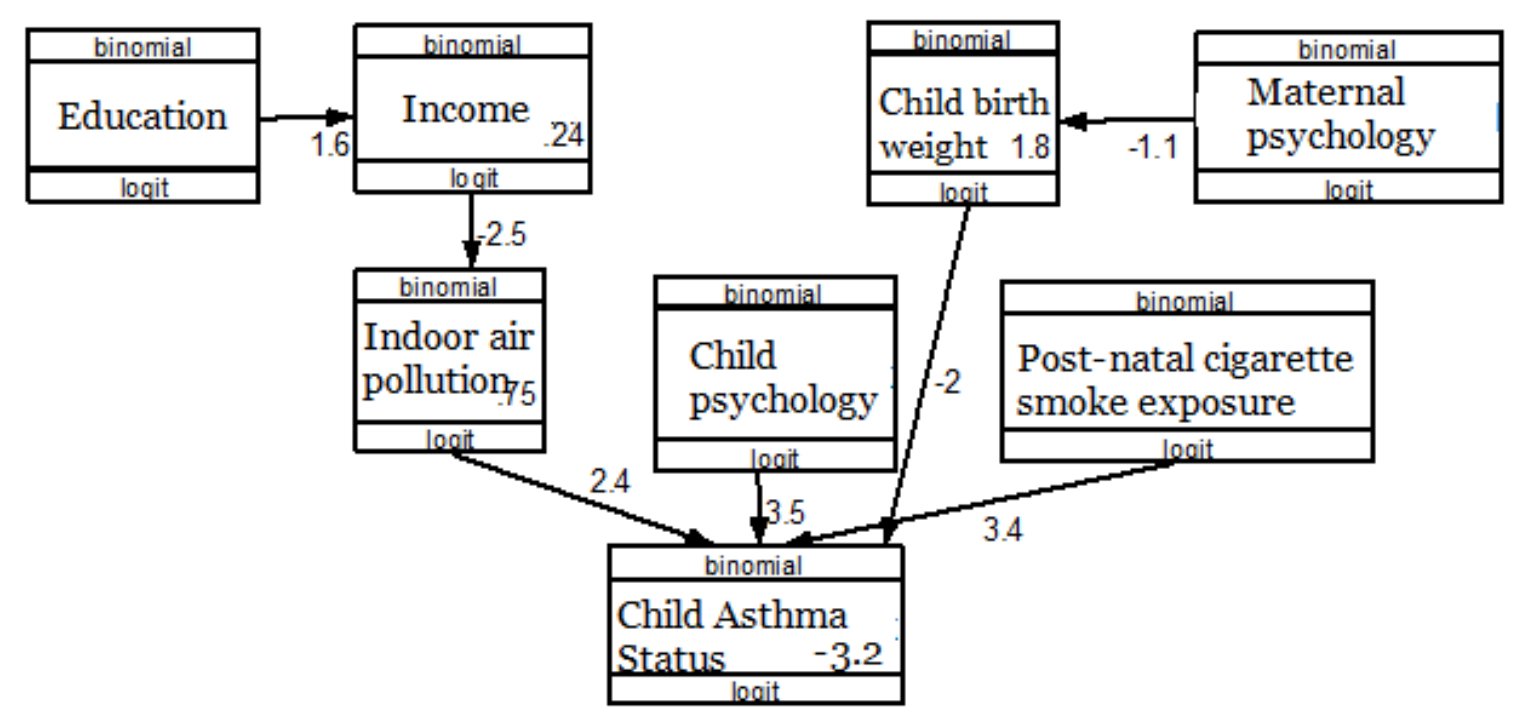

Figure 1. Model Identification of Path Analysis 
Journal of Maternal and Child Health (2016), 1(2): 62-72

https://doi.org/10.26911/thejmch.2016.01.02.01

Table 3. Result of Path Analysis on the Effect of Biopsychosocial and Environmental Exposure Toward Asthma Incidences in Surakarta

\begin{tabular}{|c|c|c|c|c|c|c|}
\hline & & & & 95 & $\mathbf{C I}$ & \\
\hline Dependent Var & & Independent variable & b & $\begin{array}{c}\text { Lower } \\
\text { Limit }\end{array}$ & $\begin{array}{l}\text { Upper } \\
\text { Limit }\end{array}$ & $\mathbf{p}$ \\
\hline Direct Effect & & & & & & \\
\hline Child Asthma & $\leftarrow$ & High indoor air pollution & 2.43 & 0.60 & 4.27 & 0.009 \\
\hline Child Asthma & $\leftarrow$ & High child stress & 3.49 & 1.18 & 5.81 & 0.003 \\
\hline Child Asthma & $\leftarrow$ & $\begin{array}{l}\text { High exposure of cigarrete } \\
\text { smoke }\end{array}$ & 3.44 & 1.07 & 5.80 & 0.004 \\
\hline $\begin{array}{l}\text { Child Asthma } \\
\text { Indirect Effect }\end{array}$ & $\leftarrow$ & Child birth weight $\geq 2,500 \mathrm{~g}$ & -2.01 & -3.95 & -0.07 & 0.041 \\
\hline Family Income & $\leftarrow$ & $\begin{array}{l}\text { Maternal education } \geq \text { High } \\
\text { school }\end{array}$ & 1.57 & 0.62 & 2.52 & $<0.001$ \\
\hline $\begin{array}{l}\text { Indoor Air } \\
\text { Pollution }\end{array}$ & $\leftarrow$ & $\begin{array}{l}\text { Family income } \geq \text { Regional } \\
\text { Minimum Wage }\end{array}$ & -2.48 & $-3 \cdot 5^{2}$ & -1.44 & $<0.001$ \\
\hline $\begin{array}{l}\text { Child birth weight } \\
\geq 2,500 \mathrm{~g} \\
\text { Log Likelihood }=- \\
\mathrm{AIC}=361.90 \\
\mathrm{BIC}=391.10\end{array}$ & $\begin{array}{l}\leftarrow \\
9.95\end{array}$ & $\begin{array}{l}\text { High maternal stress during } \\
\text { gestational period }\end{array}$ & -1.13 & -2.18 & -0.08 & 0.035 \\
\hline
\end{tabular}

\section{DISCUSSION}

1. The effect of maternal education and family income on child asthma

The result of the study indicated that there was a positive and significant effect of maternal educational level and family income toward child asthma incidences. Educational level affects one's occupation. The higher the educational level is, the easier in finding job will be to earn higher income than Regional Minimum Wage, in contrast, the lower the educational level is, the more difficult or less easy to find job will be to earn income more than Regional Minimum Wage

The result of the study is in line with a study conducted by Dharmayanti et al., (2015) that mentioned that household with high social economy status, whether it is from educational side, income and occupation, possesses bigger economy capability to maintain the family health condition and will strive to make the family leads a healthy life. Accomplishment on higher education improves family income and productivity. Education is a way to the betterment and achieving family's social and economy wel- fare. Other study by Thakur et al., (2013) also mentioned that low educational status and income are associated with the high prevalence of asthma.

Observing maternal educational background as the study subjects, it was revealed that most mother were $\geq$ Senior High School. Relatively decent educational level leads to the capability to absorb the information about asthma and the preventions. The information concerning the disease is obtained from mass media, information from trusted persons (family, relatives, and others) also from health workers when the mothers take the children to get medical treatment.

Family with higher income has higher awareness in prevention efforts. Prevention effort is any deed conducted to prevent recurrence. The efforts include getting medical treatment or regular medical checkup, nutritious foods, preparing emergency drugs for sudden asthma attack, and healthy environment. Meanwhile family with low education gets low-paying jobs. Family income level which is lower than regional minimum wage 
affects family awareness to conduct prevention efforts (Maidartati dan Persaulian, 2015).

2. The effect of family income and indoor air pollution on child asthma

The result of the study indicated that there was a negative and significant effect of family income and indoor air pollution toward child asthma incidences. The higher the income is, the easier to meet family daily needs and other needs, on the contrary, the lower the income is, the more difficult for the family to meet their daily needs and other needs. The result is in line with the result of a study by Irawan and Windi (2012) which stated that there is a significant different between asthma patients and non-asthma patients with low economy status toward home environment. Low income increase the risk of asthma related to poor housing condition.

A parallel study was also conducted by Fattore et al., (2015) which stated that children from family with low social economy status are more at risk to undergo stresssed situation and heavy disease incidences. The situation develops negative and unhealthy behaviors by some members of the family such smoking activity and increasing the concentration of indoor air pollution that may affect pulmonary function. Social economy is a determinant factor of home environmental cleanliness. Family whose household cleanliness is less will increase indoor air pollution, therefore it affects on asthma incidences and asthma attacks also children's body immune.

Income is all earnings obtained by family whether in a form of money and services. People with small earnings can only afford to meet their daily needs. Middle income family are more aimed to meet proper basic necessities such food, clothes, housing, education, and others, whereas well-off fa- mily with high income are able to meet all the necessities they desire (Ravik, 2008).

\section{The effect of indoor air pollution on child asthma}

The result of the study indicated that there was a positive and significant effect of indoor air pollution and child asthma incidences. It means a house with high exposure of air pollution might increase asthma incidences. The result of the study is in line with a study by Mc Connel et al., (2010) which stated that both indoor and outdoor (at school) air pollution greatly contribute to child asthma development. Similar study was also conducted by Zheng et al., (2015) which stated that the impact of short term exposure of indoor air pollution may increase the risk of asthma exacerbations.

Air pollution is a condition in which air contains chemicals, particles, other living organisms that generate harm and inconvenience to humans. Indoor air pollution may generate serious health threat, such as perfume spray, mosquito spray, dust in the closet, cigarette smoke and others. For asthma patients, the inflammation response occurs higher than healthy individuals.

Intensive exposure of various pollutants is associated with various forms of respiratory disorder, deterioration of pulmonary function, as well as other chronic respiratory system diseases such as asthma and chronic obstructive pulmonary disease. The occurring mechanism is the continuous exposure will generate the occurrence of repeated inflammation responses and trigger permanent respiratory tract damage (Hari et al., 2010).

\section{The effect of maternal psychology during gestational on child asthma}

The result of the study indicated there was a negative and significant effect of maternal psychology during gestational and child birth weight toward child asthma. It means, mother who undergo heavy stress during 
gestational period has small or low possibility to give birth to an infant with birth weight $\geq 2,500 \mathrm{~g}$. the study is in line with a study by Rasyid et al. (2013) which stated that heavy stress suffered during pregnancy, significantly gives risks of Low Birth Weight with 1.7 times higher risk than mothers who do not undergo stress or mild stress during pregnancy.

Another study by Monk et al., (2012) stated that heavy psychological stress during pregnancy increase the risk of prematurity, low birth weight, nervous developmental and cognitive inhibition, hyperactivity disorder, and other mental disorders. The result of meta analysis of a study by Van de loo et al., (2016) also revealed that prevalence of wheezing, asthma and other respiratory symptoms is higher on children whose mothers underwent heavy stress during gestational period compare to those whose mothers did not undergo stress.

A study by Dunkel and Tanner (2012) revealed that theoretically pregnant women who undergo various pressures both physically and psychologically, are generated by various factors. The condition triggers the increase of cortisol hormone and stimulates prostaglandin hormone for uterus to contracting before its time that leads blood vessels to contracting that fetus suffers from nutrient deficiency through placenta and potentially to give birth to low birth infant.

\section{The effect of child low birth weight on child asthma}

The result of the study indicated that there was a positive and significant effect of child birth weight and child asthma incidences. It means, low birth weight may increase the rate of child asthma incidences, on the contrary, normal birth weight may reduce child asthma incidences. The study is in line with a study by Liu et al., (2014) which mentioned that low birth weight is associated with limited normal development of lungs and affects asthma development in the child's future life. Children with low birth weight are likely to undergo respiration function deterioration and have increasing risk to chronic respiratory diseases during their childhood.

Based on the result of the study it was found that low birth weight is associated with child asthma incidences. Low birth weight is one of the risk factors of respiratory diseases such as hyaline membrane disease, respiratory tract infection including asthma. In baby with low birth weight is often found organs immaturity such as respiratory organ, it affects the initial adaptation process in responding various harmful exposures during infant and early age such as cigarette smoke, saw dust, and antibiotic administration that generates remodeling process of respiratory tract or airway remodeling (AR) (Rasyid et al., 2013).

Another mechanism that underlies the association between low birth weight and asthma is the increasing sensitivity toward allergens, inflammation, and bronchial hypersensitivity. The result of the study is in accordance with a study conducted by $\mathrm{Xu}$ et al (2014) in China that reported that at the age of 5 there are more children with history of low birth weight who suffer from asthma.

\section{The effect of child psychological disorder on child asthma}

The result of the study indicated that there was a positive and significant effect of child psychological disorder toward child asthma incidences. It means a child who suffers from asthma has higher psychological disorder than a child who does not suffer from asthma. It is in line with a study by Putu (2012) that stated that asthma patients who undergo heavy psychological disorder (emotionally stressed) have 4.4 times bigger possibility to have asthma attack than asthma patients who do not undergo heavy psychological disorders. 
The result of the study is similar with a study by Budayani (2015) who conducted a study about the level of anxiety with the sleeping quality of asthma patients, that there was a significant effect of level of anxiety and sleeping quality toward asthma morbidity. Therefore it can be concluded that stress or emotional disorder may become the trigger of asthma attack and it is possible to aggravate the existing asthma attack. Stress may deliver someone to certain anxiety level that triggers the release of histamine and leukotrienes which generate respiratory tract constriction in which it is marked by sore throat and shortness of breath, and eventually may lead to asthma attack.

Based on child psychological disorders, the average children who suffer from asthma undergo stress for the occurrence of asthma attack and most children with no asthma do not undergo heavy psychological disorders for the occurrence of asthma attack. The researcher has discovered that the cumulative level of stress may cause physiological allostatictol burden that may affect a child's body. In addition to general physiological burden, the effect of stress to biological system that relevant to specific disease may have implication to the disease (Harsono, 2014).

\section{The effect of post-natal cigarette smoke toward child asthma}

The result of the study indicated there was a positive and significant effect of post labor cigarette smoke toward child astma incidence. It means, high exposure of cigarette smoke may increase the asthma incidences on children. The study is in line with a study by Burke et al. (2012) which stated that high exposure of cigarette smoke in the family increase the severity and frequency of asthma attack on children. Children with asthma because both parents smoke at least will be two times likely to suffer from asthma symptoms throughout the year than those whose parents do not smoke.

Another study by Millet et al. (2013) indicated that as the result of cigarette smoke exposure during gestational period, a group of people will be at high risk to contract a life time chronic respiratory disease. Another study showed that asthma patients who are exposed to cigarette smoke for one hour will suffer from 20\% pulmonary function damage. On children, cigarette smoke will give the more severe effect than adults, it is because children's respiratory tract is narrower, that the frequency of breathing is faster that adults. As the result, the amount of cigarette smoke that enter respiratory tract is a lot more compare to body weight, since the body immune system does not yet develop therefore the emergence of asthma symptoms on children is faster than that on adults. The exposure of cigarette smoke (passive smoker) as the result of smoking parents may generate the occurrence of inflammation reaction in respiratory tract that makes children short of breath. The reason of the condition is because of the content of harmful contaminant in cigarette smoke that may cause respiratory disorder on asthma patients (Rasyid et al., 2013).

The conclusion of the study is that there is a direct effect of post-natal cigarette smoke exposure, child psychological disorder toward child asthma incidences. There is an indirect effect of maternal education through family income and indoor pollution, and an indirect effect of maternal psychology during gestational period through child birth weight toward child asthma incidences.

\section{REFERENCES}

Budayani SS (2015). Hubungan Tingkat Kecemasan dengan Kualitas Tidur pada Penderita Asma di RSUD Kabupaten 
Karanganyar. Program Studi S1 Keperawatan Stikes Kusuma Husada Surakarta.

Burke H, Leonardi BJ, Hashim A, PineAbata H, Chen Y, Cook DG, Britton JR (2012). Prenatal and passive smoke exposure and incidence of asthma and wheeze: systematic review and metaanalysis. Pediatrics, 129(4): 735-744.

Dharmayanti I, Hapsari D, Azhar K (2015). Asthma among Children in Indonesia: Causes and Triggers. Jurnal Kesehatan Masyarakat Nasional, 9(4): 320-326.

Dinas Kesehatan Kota Surakarta (2014). Profil Kesehatan Kota Surakarta Tahun 2014. Departemen Kesehatan. Surakarta.

Fattore GL, Santos Carlos Antonio de ST, Barreto ML (2015). Sosioeconomic and Environmental Determinants of Adolescent Asthma in Urban Latin America: an Ecological Analysis. Cad. Saude Publica, 31(11): 2367-2378.

Ferreira LN, Brito U, Ferreioera PL (2010). Quality of life in asthma patients. Rev Port Pneumol, 16(1): 23-55.

Harsono A (2014). Stres psikologis dapat mencetuskan serangan sesak pada anak asma. Dokter Spesialis Anak, Konsultan Alergi-Imunologi, Guru Besar Fakultas Kedokteran Universitas Airlangga.

Machmud R (2009). Pengaruh Kemiskinan Keluarga pada Kejadian Pneumonia Balita di Indonesia. Jurnal Kesehatan Masyarakat Nasional, 4(1): 36-41.

Maidartati, Persaulian P (2015). Gambaran Pengetahuan Ibu Hamil Trimester 1 tentang Pengaruh Rokok terhadap Tumbuh Kembang Janin di Poli Kandungan RSUD Kota Bandung. Jurnal Ilmu Keperawatan, 3(1): 38-50.

Mc Connell R, Islam T, Shankardass T, Jerrett M, Lurmann F, Gauderman J, Avol ED (2010). Childhood Incident
Asthma and Traffic-Related Air Pollution at Home and School. Environ Health Perspect, 118(7): 1021-1026.

Millett C, Lee T, Laverty A, Glantz AM (2013). Hospital admissions for childhood asthma after smoke-free legislation in England. Pediatrics, 131(2): 495-501.

Monk C, Spicer J, dan Champagne FA (2012). Linking Prenatal Maternal Adversity to Developmental Outcomes in Infants: The Role of Epigenetic Pathways. Dev Psychopathol, 24: 1361-176.

Murti B (2016). Pengaruh Faktor Biopsikososial Ibu Hamil Terhadap Kesehatan Anak di Kemudian Hari dan Usia Dewasa. Program Studi Pascasarjana Ilmu Kesehatan Masyarakat. Universitas Seblas Maret, Surakarta.

Oemiati R, Sihombing M, Qomariah (2010). Faktor-Faktor yang Berhubungan dengan Penyakit Asma di Indonesia. Media litbang kesehatan, 20(1): 41-49.

Perhimpunan Dokter Paru Indonesia (2010). Asma Pedoman Praktis Diagnosis dan Penatalaksanaan di Indonesia. Revisi 2010. Jakarta: Balai Penerbit FK-UI.

Putu ELN (2012). Analisis Faktor-Faktor Pemicu Dominan Terjadinya Serangan Asma pada Pasien Asma. Thesis. Fakultas Ilmu Keperawatan Program Magister Ilmu Keperawatan Universitas Indonesia, Jakarta.

Raheleh Z, Ahmad A, Abtin H, Smit HA, Roghaye Z, Sara H, Siavash R (2016) The Association between Birth Weight and Gestational Age and Asthma in 6-7 and 13-14 Year Old Children. Scientifica, 110.

Rasyid PS, Hakim BH, Sirajuddin S (2013). Risk Factors of Low Birth Weight in Prof. DR. H. Aloei Saboe General Hospital Gorontalo City Gorontalo 
Provincie 2012. Staf Kebidanan Politeknik Kesehatan. Gorontalo.

Ravik K (2008). Sosiologi Pendidikan. Surakarta: UNS Press dan LPP UNS.

Schetter C, Tanner L (2012). Anxiety, Depression and Stress in Pregnancy: Implications for Mothers, Children, Research, and Practice. Curr Opin Psychiatry, 25: 141-148.

Sihombing M, Alwi Q, Nainggolan O (2010). Faktor-faktor yang Berhubungan dengan Penyakit Asma Pada Usia $\geq 10$ Tahun di Indonesia (Analisis Data Riskesdas 2007). Jurnal Respirologi Indonesia, 30(2): 85-91.

Thakur S, Oh SS, Nguyen EA, Martin M, Roth LA, Galanter J, Gignoux CR, Eng $C$ (2013). Socioeconomic Status and Childhood Asthma in Urban Minority Youths. Am J Respir Crit Care Med, 188(10): 1202-1209.

Van de Loo Kim FE, Van Gelder MM, Roukema J, Roeleveld N, Merkus PJ, Verhaak CM (2016). Prenatal Maternal Psychological Stress and Childhood Asthma and Wheezing: a Meta-Analy- sis. European Respiratory Journal, 133: 1-23.

Vernon MK, Wiklund I, Bell JA, Dale P, Chapman KR (2012). What Do We Know about Asthma Triggers? A Review of the Literature. J Asma, 49(10): 991-998.

Wright RJ (2010). Perinatal stress and early life programming of lung structure and function. Biol Psychol, 84 (1): 4656.

Xu XF, Li YJ, Sheng YJ, Liu JL, Tang LF, Chen ZM (2014). Effect of Low Birth Weight on Childhood Asthma: A MetaAnalysis. BMC Pediatrics, 14 (275): 28.

Zheng XY, Ding H, Jiang LN, Chen SW, Zheng JP, Qiu M (2015). Association between Air Pollutants and Asthma Emergency Room Visits and Hospital Admission in Time Series Studi: A Systematic Review and Meta-Analysis. Journal Plos one, 10(9): 1-24. 